\title{
DNA methylation patterns of steroid receptor genes ESR1, ESR2 and $P G R$ in deep endometriosis compromising the rectum
}

\author{
JOANA LADEIRA MEYER ${ }^{1 *}$, DANIELA ZIMBARDI ${ }^{*}$, SÉRGIO PODGAEC $^{2}$, RENEE LAUFER AMORIM $^{3}$, \\ MAURÍCIO SIMÕES ABRÃO ${ }^{2}$ and CLÁUDIA APARECIDA RAINHO ${ }^{1}$ \\ ${ }^{1}$ Department of Genetics, Institute of Biosciences, São Paulo State University (UNESP), Botucatu, São Paulo; \\ ${ }^{2}$ Department of Obstetrics and Gynecology, São Paulo University (USP), São Paulo; \\ ${ }^{3}$ Department of Clinical Veterinary Medicine, São Paulo State University (UNESP), Botucatu, São Paulo, Brazil
}

Received September 26, 2013; Accepted December 17, 2013

DOI: $10.3892 /$ ijmm.2014.1637

\begin{abstract}
Endometriosis is characterized by the presence of endometrial-like tissue located outside the uterine cavity. Recent evidence suggests that endometriosis may be an epigenetic disease, as well as an estrogen-dependent disease. Based on the unique steroid hormone receptor expression profile observed in endometriotic lesions as compared to eutopic endometrium, the present study aimed to gain further insight into the DNA methylation patterns of alternative promoters of the steroid receptor genes ESR1, ESR2 and PGR in intestinal deep endometriosis, one of the most aggressive forms of endometriosis. The DNA methylation patterns were evaluated by methylation-specific polymerase chain reaction (MS-PCR) after bisulfite modification in 44 endometriotic tissues as well as in 7 matched eutopic endometrium. No differences in the DNA methylation were observed for the ESR 1 and ESR 2 genes. Methylation of the PGR gene was observed in $39 \%$ (17 out of 44 ) and 19\% (7 out of 37) of the cases in the promoter regions $\mathrm{B}(P G R B)$ and $\mathrm{A}(P G R A)$,
\end{abstract}

Correspondence to: Dr Cláudia Aparecida Rainho, Department of Genetics, Institute of Biosciences, São Paulo State University (UNESP), Botucatu, São Paulo 18618-970, Brazil

E-mail: rainho@ibb.unesp.br

*Contributed equally

Abbreviations: ASRM, American Society for Reproductive Medicine; COX-2, cyclooxygenase-2; CYP19A1, cytochrome P450, family 19, subfamily A, polypeptide 1; DNMTs, DNA methyltransferases; ESR1 or ER $\alpha$, estrogen receptor 1 or $\alpha$; ESR2 or ER $\beta$, estrogen receptor 2 or $\beta$; hMLH1, mutL homolog 1 , colon cancer, nonpolyposis type 2; H\&E, hematoxylin and eosin; HOXA10, transcription factor homeobox 10A; MS-PCR, methylation-specific polymerase chain reaction; NR5A1 or SF-1, nuclear receptor subfamily 5 or steroidogenic factor-1; PGR or PgR, progesterone receptor; TP16, cyclin-dependent kinase inhibitor $2 \mathrm{~A}$

Key words: DNA methylation, endometriosis, epigenetics, $\mathrm{CpG}$ island, steroid hormone receptors, biomarkers respectively. Both PGR promoter regions were methylated in 3 cases. $P G R B$ methylated alleles were detected exclusively in the endometriotic lesions when compared to the eutopic endometrium obtained from the same patient. The effect of DNA methylation in inhibiting the $P G R$ gene expression was corroborated by immunostaining for $\mathrm{PgR}$ protein in a subset of tissue samples. The present study demonstrated that epigenetic changes occur in both promoter regions of the $P G R$ gene in intestinal endometriosis. Since eutopic and ectopic tissues do not respond sufficiently to progesterone in women with endometriosis, further study is necessary to evaluate the effect of epigenetic alterations in progesterone-resistance in this enigmatic disease.

\section{Introduction}

In the past two decades, epigenetic mechanisms have been recognized as key factors in the development of complex human disorders, including cancer, and neurodegenerative, neurological and autoimmune diseases (1). Changes in chromatin conformation constitute the basis of epigenetic effects since they can alter gene expression without depending on DNA sequence changes. Chromatin epigenetic mechanisms include DNA methylation and post-translational covalent modifications of histones. These modifications comprise heritable alterations that regulate essential biological processes, such as gene and microRNA expression, cellular differentiation, X-chromosome inactivation and genomic imprinting. DNA methylation is the most widely studied and best characterized epigenetic modification of the human genome (2). This epigenetic modification is catalyzed by DNA methyltransferases (DNMTs), which add a methyl group to the carbon 5 of cytosines that are followed by a guanine. Thus, DNA methylation occurs almost exclusively in the context of a 5'-CpG-3' dinucleotide, particularly in dense $\mathrm{CpG}$ regions termed $\mathrm{CpG}$ islands. Promoter-specific $\mathrm{CpG}$ island hypermethylation is known to be associated with gene silencing due to their transcription repression effect (3).

Recent evidence indicates that endometriosis, an enigmatic disease in which endometrial-like tissue is detected outside the uterus, is also an epigenetic disease (4-6). This hypothesis was based on the abnormal DNA methylation patterns observed in 
the promoter regions of specific genes (7-12) and the higher expression levels of DNMTs in endometriotic lesions in comparison with normal endometrium (13). The first evidence of increased levels of DNA methylation of a specific gene came from a pioneer study by Martini et al (7), which found aberrant DNA methylation in the tumor-suppressor genes, cyclin-dependent kinase inhibitor 2A (TP16) and mutL homolog 1, colon cancer, nonpolyposis type $2(h M L H 1)$ in one and four samples of endometriosis, respectively. Subsequently, by using a candidate gene approach, other studies have described aberrant methylation patterns in the promoter region of genes encoding the transcription factor homeobox 10A (HOXA10) (8), progesterone receptor isoform $\mathrm{B}(P G R)(9)$, estrogen receptor $2, \mathrm{ER} \beta$ (ESR2) (10), nuclear receptor subfamily 5, group A, member 1 (NR5A1, primarily named SF-1 or steroidogenic factor-1) (11) and cyclooxygenase-2 (COX-2) (12) in endometriotic lesions derived from different anatomical sites. Furthermore, endometriotic cells treated in vitro with the demethylating agent 5-aza-2'deoxycytidine showed an increase in the expression of aromatase mRNA, suggesting that DNA methylation of the CYP19A1 aromatase gene also occurs in stromal cells from endometriotic lesions (14).

Endometriosis is believed to be an estrogen-dependent disease characterized by the loss of progesterone-protective signaling in endometriotic cells. Xue et al (10) demonstrated that this effect could be related to hypomethylation of the ESR2 gene in stromal endometriotic cells, which could lead to an increase in the expression of estrogen receptor $\beta(\mathrm{ER} \beta)$. These authors also demonstrated the presence of DNA methylation in a specific region of ESR2 that confers promoter activity and co-localizes with a $\mathrm{CpG}$ island: in vitro methylation was correlated with inactivation of this promoter. Subsequently, it was proposed that the increased expression of $\operatorname{ER} \beta$, due to the hypomethylation of its coding gene, could inhibit the expression of the $P G R$ gene (15). In addition, hypermethylation of the $P G R$ gene, particularly at promoter $\mathrm{B}$, was also observed in the epithelial component of endometriotic lesions (9), with consequent decrease in the expression of its transcript.

Overall, steroid hormone receptor genes show a complex pattern of regulation involving multiple promoters and alternative mRNA isoforms. The ESRl gene has two proximal promoters (transcripts $\mathrm{A}$ and $\mathrm{B}$ ) located within $\sim 2 \mathrm{~kb}$ of the translation start site and an upstream promoter $C(16,17)$. Similarly, the $P G R$ gene has two alternative transcripts regulated by two promoter-specific regions for the $P G R A$ and $P G R B$ isoforms, which are associated with well-characterized CpG islands (18). The ESR2 gene also presents alternatively spliced transcript variants and distinct promoters regulated by DNA methylation (19), although not associated with the presence of classic $\mathrm{CpG}$ islands.

Potentially, aberrant DNA methylation can disrupt the effects of hormone steroids due to changes in the expression levels of its receptors and may influence the origin and progression of endometriosis. Thus, the present study was conducted to investigate the methylation patterns of the alternative promoter regions of the ESRI, ESR2 and PGR genes in intestinal deep endometriosis, which accounts for $8-12 \%$ of all endometriosis. This condition is characterized by multifocal infiltrating and aggressive lesions associated with pelvic pain and infertility (20).
Table I. Clinical and histopathological data of the patients with intestinal deep endometriosis.

\begin{tabular}{lcc}
\hline & $\begin{array}{c}\text { No. of } \\
\text { cases }\end{array}$ & $\begin{array}{c}\text { Percentage } \\
(\%)\end{array}$ \\
\hline Clinical features/symptoms & & \\
Infertility & $24 / 44$ & 54 \\
Dyspareunia & $29 / 44$ & 66 \\
Dysmenorrhea & $39 / 44$ & 89 \\
ASMR stage (n=44) & & \\
I & 7 & 16 \\
II & 6 & 14 \\
III & 3 & 7 \\
IV & 28 & 63 \\
Histological classification ${ }^{\mathrm{b}}$ (n=36) & & \\
Well-differentiated glandular pattern & 1 & 3 \\
Glandular of mixed differentiation & 26 & 72 \\
and stromal pattern & & \\
Undifferentiated glandular and & 9 & 25 \\
stromal pattern & & \\
Phase of the menstrual cycle (n=39) & & 87 \\
Proliferative & 34 & 5 \\
Secretory & 2 & \\
Menstrual & 3 & \\
\hline
\end{tabular}

${ }^{\text {aT }}$ The stage was determined according to the Revised American Society for Reproductive Medicine classification of endometriosis (21). ${ }^{\mathrm{b}}$ The histological classification was determined according to Abrao et al (22).

\section{Materials and methods}

Biological samples. Fresh endometriotic tissues were collected from 44 premenopausal patients (mean age, $35.1 \pm 6.8$ years) who underwent laparoscopy for diagnosis and surgical resection (nodule resection or segmental resection of the rectum). Laparoscopy was indicated after clinical evaluation and imaging methods (transvaginal ultrasound with bowel preparation). Matched eutopic endometrial tissue samples were collected by curettage simultaneously from 7 of these patients. No patient had clinical diagnosis of immunological diseases or cancer. The classification system followed the American Society for Reproductive Medicine's recommendations for staging (I-IV) (Revised American Fertility Society classification of endometriosis - ASRM, 1997) (21). After histopathological confirmation of the diagnosis, lesions were morphologically classified as well-differentiated glandular pattern, stromal pattern, glandular pattern of mixed differentiation and undifferentiated glandular pattern according to previously described criteria (22). In addition, the phase of the menstrual cycle was also estimated by histological evaluation. The clinical and histopathological data are provided in Table I. Approval for the study was obtained from the Institutional Review Board of the Hospital das Clínicas and the Faculdade de Medicina da Universidade de São Paulo (CAPPesp - USP). 
Table II. Primer sequences, reaction and amplification conditions used in the MS-PCR analysis.

\begin{tabular}{|c|c|c|c|c|}
\hline Primer & Oligonucleotide sequence & $\begin{array}{l}\text { Reaction } \\
\text { conditions }\end{array}$ & $\begin{array}{l}\text { Amplification } \\
\text { conditions }\end{array}$ & $\begin{array}{l}\text { Amplicon } \\
\text { (bp) }\end{array}$ \\
\hline PGRA-UF & 5'-ATGGGTTATTTTTTTTTTG-3' & $\left(\mathrm{MgCl}_{2}\right) 2.5 \mathrm{mM}$ & 1 cycle: $95^{\circ} \mathrm{C}-10 \mathrm{~min} ; 35$ cycles: & 99 \\
\hline PGRA-UR & 5'-TAAAATATACACCCТCCACA-3' & (Primers) $0.08 \mu \mathrm{M}$ & $95^{\circ} \mathrm{C}-1 \mathrm{~min}, 51^{\circ} \mathrm{C}-1 \mathrm{~min}$ & \\
\hline PGRA-MF & 5'-ACGGGTTATTTTTTTTTCG-3' & & $72^{\circ} \mathrm{C}-1 \mathrm{~min} ; 1$ cycle: $72^{\circ} \mathrm{C}-1 \mathrm{~min}$ & \\
\hline PGRA-MR & 5'-TAAAATATACGCCCTCCACG-3' & & & \\
\hline PGRB-UF & 5'-TGATTGTTGTTTGTAGTATG-3' & $\left(\mathrm{MgCl}_{2}\right) 4.0 \mathrm{mM}$ & 1 cycle: $95^{\circ} \mathrm{C}-10 \mathrm{~min} ; 35$ cycles: & 200 \\
\hline PGRB-UR & 5'-CAACAATTTAATAACACACA-3' & (Primers) $0.24 \mu \mathrm{M}$ & $95^{\circ} \mathrm{C}-1 \mathrm{~min}, 50^{\circ} \mathrm{C}-1 \mathrm{~min}$ & \\
\hline PGRB-MF & 5'-TGATTGTCGTTCGTAGTACG-3' & & $72^{\circ} \mathrm{C}-1 \mathrm{~min} ; 1$ cycle: $72^{\circ} \mathrm{C}-1 \mathrm{~min}$ & \\
\hline PGRB-UR & 5'-CGACAATTTAATAACACGCG-3' & & & \\
\hline ESR1A-UF & 5'-GGATATGGTTTGTATTTTGTTTGT-3' & $\left(\mathrm{MgCl}_{2}\right) 2.5 \mathrm{mM}$ & 1 cycle: $95^{\circ} \mathrm{C}-10 \mathrm{~min}$ & 123 \\
\hline ESR1A-UR & 5'-ACAАACAАTТСАААААСТССААСТ-3' & (Primers) $0.16 \mu \mathrm{M}$ & 35 cycles: $95^{\circ} \mathrm{C}-1 \mathrm{~min}$ & \\
\hline ESR1A-MF & 5'-GATACGGTTTGTATTTTGTTCGC-3' & & $54^{\circ} \mathrm{C}(\mathrm{U}) / 50^{\circ} \mathrm{C}(\mathrm{M})-1 \mathrm{~min}$ & 121 \\
\hline ESR1A-MR & 5'-CGAACGATTCAAAAACTCCAACT-3' & & $72^{\circ} \mathrm{C}-1 \mathrm{~min} ; 1$ cycle: $72^{\circ} \mathrm{C}-1 \mathrm{~min}$ & \\
\hline ESR1B-UF & 5'-TTTATTGTTATTTATTTAGT-3' & $\left(\mathrm{MgCl}_{2}\right) 4.0 \mathrm{mM}$ & 1 cycle: $95^{\circ} \mathrm{C}-10 \mathrm{~min}$ & 180 \\
\hline ESR1B-UR & 5'-AAAAATATACTCACATATACA-3' & (Primers) $0.16 \mu \mathrm{M}$ & 35 cycles: $95^{\circ} \mathrm{C}-1 \mathrm{~min}$ & \\
\hline ESR1B-MF & 5'-TTTATTGTTATTTATTTAGC-3' & & $47^{\circ} \mathrm{C}(\mathrm{U}) / 49^{\circ} \mathrm{C}(\mathrm{M})-1 \mathrm{~min}$ & \\
\hline ESR1B-MR & 5'-AAAAATATACTCGCATATACG-3' & & $72^{\circ} \mathrm{C}-1 \mathrm{~min} ; 1$ cycle: $72^{\circ} \mathrm{C}-1 \mathrm{~min}$ & \\
\hline ESR2-UF & 5'-TTTGGAAGGTGGGTTTGGTT-3' & $\left(\mathrm{MgCl}_{2}\right) 3.0 \mathrm{mM}$ & 1 cycle: $95^{\circ} \mathrm{C}-10 \mathrm{~min}$ & 109 \\
\hline ESR2-UR & 5'-CACATACAAATATAATAACTAACA-3' & (Primers) $0.16 \mu \mathrm{M}$ & 35 cycles: $95^{\circ} \mathrm{C}-1 \mathrm{~min}$, & \\
\hline ESR2-MF & 5'-TTTGGAAGGTGGGTTTGGTC-3' & & $54^{\circ} \mathrm{C}-1 \mathrm{~min}, 72^{\circ} \mathrm{C}-1 \mathrm{~min}$ & \\
\hline ESR2-MR & 5'-CGCATACAAATATAATAACTAACG-3' & & 1 cycle: $72^{\circ} \mathrm{C}-1 \mathrm{~min}$ & \\
\hline
\end{tabular}

MF, methylated foward primer; MR, methylated reverse primer; UF, unmethylated foward primer; UR, unmethylated reverse primer; bp, base pair.

All samples were collected after each patient provided informed consent.

All tissue samples were kept on dry ice immediately after surgical resection and stored at $-80^{\circ} \mathrm{C}$. Subsequently, the frozen tissue samples were manually macrodissected using custom-built needles (23).

DNA extraction and methylation analysis. Genomic DNA was obtained by standard sodium dodecyl sulfate/proteinase $\mathrm{K}$ digestion, followed by phenol/chloroform extraction and ethanol precipitation. DNA conversion by sodium bisulfite was performed using an established protocol (24). Methylationspecific polymerase chain reaction (MS-PCR) was used to evaluated the DNA methylation patterns of the alternative promoter regions $\mathrm{A}$ and $\mathrm{B}$ of the $P G R$ and $E S R I$ genes as well as a promoter region of the ESR2 gene. Methylated and unmethylated sequences of each gene were detected using specific oligonucleotides as previously described by Sasaki et al (25). The reactions were performed in a total volume of $25 \mu \mathrm{l}$ containing $200 \mu \mathrm{M}$ of each dNTP, $15 \mathrm{mM}$ of Tris- $\mathrm{HCl} \mathrm{pH} \mathrm{8.0,50} \mathrm{mM} \mathrm{of} \mathrm{KCl}$ and 1 unit of AmpliTaq Gold DNA polymerase (Applied Biosystems, Foster City, CA, USA). Amplification and additional reaction conditions are listed in Table II. The amplified products were visualized after electrophoresis on a $6 \%$ polyacrylamide gel, followed by silver nitrate staining. Water blanks were included in each assay.
For the standardization of the DNA methylation analysis, MS-PCR assays were initially performed in three breast cancer cell lines showing a known hormone receptor expression profile (26). The cell lines selected were MDA-MB-231, classified as negative for ER and $\mathrm{PgR}$ protein expression, and T47D and MCF-7 cells which are positive for both receptors. Furthermore, gene-specific methylation data for these cell lines, available in the Cancer Methylome System (27), were obtained in silico and used as reference in the optimization step of the MS-PCR assays in the present study.

Immunohistochemical analysis. $\mathrm{ER} \alpha, \mathrm{ER} \beta$ and $\mathrm{PgR}$ protein levels were analyzed in formalin-fixed and paraffin-embedded tissues from 7 selected endometriotic tissue samples (cases $2,3,28,35,36,40$ and 42). Sections were freshly cut $(3 \mu \mathrm{m})$ and mounted on slides with organosilane (3-aminopropyl triethoxy-silane) (Sigma-Aldrich Co., St. Louis, MO, USA). Slides were deparaffinized in xylene, gradually rehydrated through a series of alcohol rinses, and washed in phosphatebuffered saline. Intrinsic peroxidase activity was blocked with hydrogen peroxidase, and the sections were incubated with the primary antibodies: RTU-ER-6F11 (Novocastra, Newcastle, UK) (dilution 1:50), monoclonal anti-human estrogen receptor $\beta 1$ (Dako Cytomation, Glostrup, Denmark) (dilution 1:60), and monoclonal anti-human progesterone receptor 1A6 (Dako, Carpinteria, CA, USA) (dilution 1:50). After incubation for $1 \mathrm{~h}$, the sections were washed in phosphate-buffered 
Table III. Clinical and histopathological features and DNA methylation of the A and B promoter regions of the PGR gene.

\begin{tabular}{|c|c|c|c|c|c|c|}
\hline \multirow[b]{2}{*}{ Parameter } & \multicolumn{3}{|c|}{$P G R A$} & \multicolumn{3}{|c|}{$P G R B$} \\
\hline & M & $\mathrm{U}$ & P-value & M & $\mathrm{U}$ & P-value \\
\hline \multicolumn{7}{|l|}{ ASMR stage $(P G R A, \mathrm{n}=37$ and $P G R B, \mathrm{n}=44)$} \\
\hline $\mathrm{I}+\mathrm{II}$ & 1 & 6 & 0.64 & 6 & 7 & 0.52 \\
\hline $\mathrm{III}+\mathrm{IV}$ & 9 & 21 & & 11 & 20 & \\
\hline \multicolumn{7}{|l|}{ Histological classification $(P G R A, \mathrm{n}=29$ and $P G R B, \mathrm{n}=36)$} \\
\hline Differentiated glandular pattern and stromal pattern & 4 & 16 & 1.0 & 9 & 18 & 1.0 \\
\hline Undifferentiated glandular and stromal pattern & 1 & 8 & & 3 & 6 & \\
\hline \multicolumn{7}{|c|}{ Phase of the menstrual cycle $(P G R A, \mathrm{n}=29$ and $P G R B, \mathrm{n}=36)$} \\
\hline Proliferative & 6 & 22 & 1.0 & 12 & 0 & 0.54 \\
\hline Secretory & 0 & 1 & & 22 & 2 & \\
\hline
\end{tabular}

M, methylated alleles; $\mathrm{U}$, unmethylated alleles.

saline, incubated for 30 min with the secondary biotinylated antibody, and for an additional 30 min with the streptavidin peroxidase complex (LSAB; Dako, Carpinteria, CA, USA). Color development was obtained with 3,3'-diaminobenzidine and counterstaining with hematoxylin and eosin (H\&E). Positive and negative controls for each marker were routinely performed during experiments. In areas of well-preserved tissue, the staining intensity of endometriotic lesions and the percentage of cells showing antibody reactivity were scored as $+1(<25 \%),+2(>25 \%$ and $<50 \%),+3(>50 \%$ and $<75 \%)$, and $+4(>75 \%)$.

Statistical analysis. Descriptive mean and percentage statistics were used to summarize patient data and the gene hypermethylation status. Associations between DNA methylation and clinical and histological parameters were evaluated using Fisher's exact test with a 5\% level of significance.

\section{Results}

The set of biological samples investigated in the present study was comprised of 44 cases of intestinal deep endometriosis. In this group of women, the most frequent symptoms were moderate to severe dysmenorrhea $(\mathrm{n}=39,89 \%)$, dyspareunia $(n=29,66 \%)$ and infertility $(n=24,54 \%)$. Moreover, the majority of the endometriotic specimens were classified as advanced stages III and IV $(\mathrm{n}=31,70 \%)$. The histological classification was able to be assessed in 36 cases indicating a predominance of glandular and stromal pattern $(n=26,72 \%)$ and an undifferentiated glandular pattern in 9 cases $(25 \%)$. In addition, the menstrual cycle stage was determined as proliferative in almost all of the tissue samples evaluated for this parameter (34/39 cases, $87 \%)$.

As expected, the presence of methylation as determined by the MS-PCR assays was inversely correlated with the expression at the protein level in the three breast cell lines investigated. Methylated alleles for PGRA, PGRB, ESRIA and ESRIB were detected in the MDA-MB-231 cell line (ER- and PgR-negative) and only unmethylated alleles were found in the T47D breast cancer cells (ER- and PgR-positive). Similarly, in the MCF-7 cells (ER- and PgR-positive) only unmethylated alleles were detected in the ESRIA, PGRA and PGRB promoter regions, while both methylated and unmethylated alleles were found in the ESRIB promoter. These methylation pattens were also confirmed in the Cancer Methylome System, which present the methylation profile generated by immunoprecipitation using the methyl-CpG binding domain of the MBD2 protein followed by high-throughput sequencing (27) (available at http://cbbiweb. uthscsa.edu/KMethylomes/) (data not shown).

Subsequently, the PGRB and ESR2 promoter methylation patterns were obtained in the 44 cases of infiltrating intestinal deep endometriosis. Unmethylated and methylated alleles were observed for the ESR2 gene in all samples analyzed. PGRB promoter methylation was observed in $39 \%$ (17/44 cases) of the endometriotic lesions. In 7 of the 44 samples, it was also possible to determine the methylation pattern in matched endometrium obtained from the same patient. No difference was observed in the ESR 2 methylation pattern in these cases; however, only unmethylated alleles were observed in the $P G R B$ promoter region. Thus, direct comparison of the $P G R B$ promoter region methylation between matched endometrium and endometriotic samples revealed a differential pattern in 4 pairs since hypermethylated alleles were specifically detected in the endometriotic tissue (Fig. 1).

In an attempt to remove the adjacent intestinal tissue in the fragments containing the endometriotic infiltrating lesions, macrodissection of the frozen tissue specimens was performed, which resulted in a limited quantity of DNA for the multiple MS-PCR tests. Thus, the MS-PCR analysis of the ESRIA, ESRIB and PGRA promoters was possible in a subset of only 37 out of 44 endometriotic lesions. While methylated and unmethylated alleles were simultaneously detected for both ESR1 promoters in all of these samples, PGRA methylated alleles were only detected in 7 lesions (19\%) (Fig. 1).

Differences in the DNA methylation frequencies in endometriotic lesions were observed for the two promoter regions of the $P G R$ gene: 14 samples were methylated at the $P G R B$ promoter, 7 were methylated at the $P G R A$ promoter, and 3 were 
A

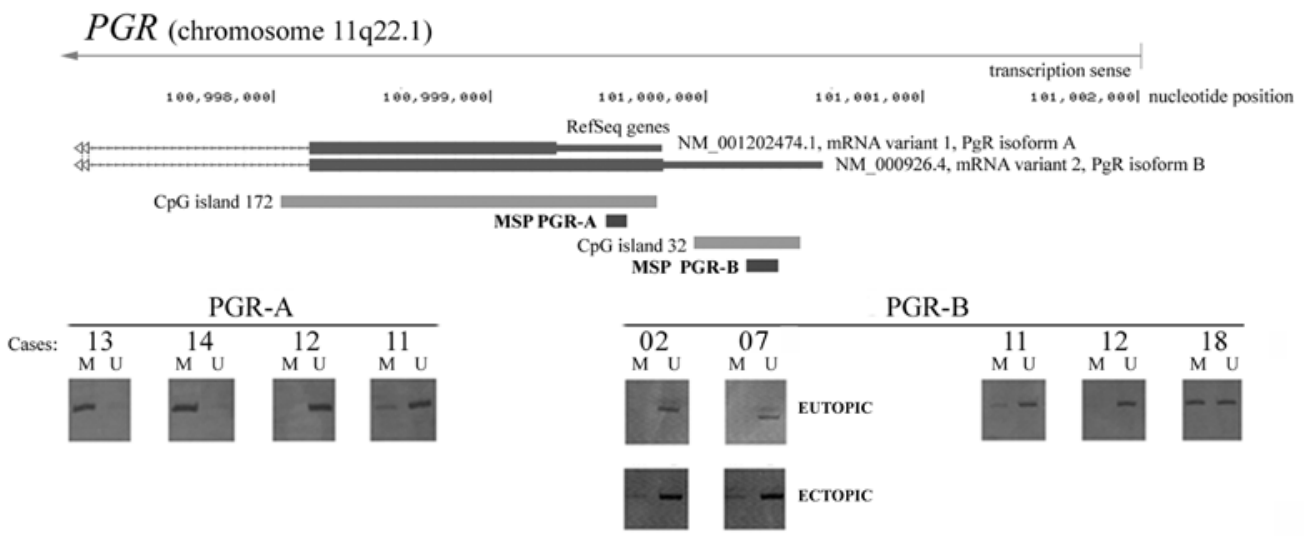

B

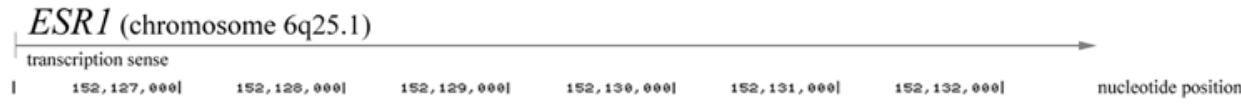
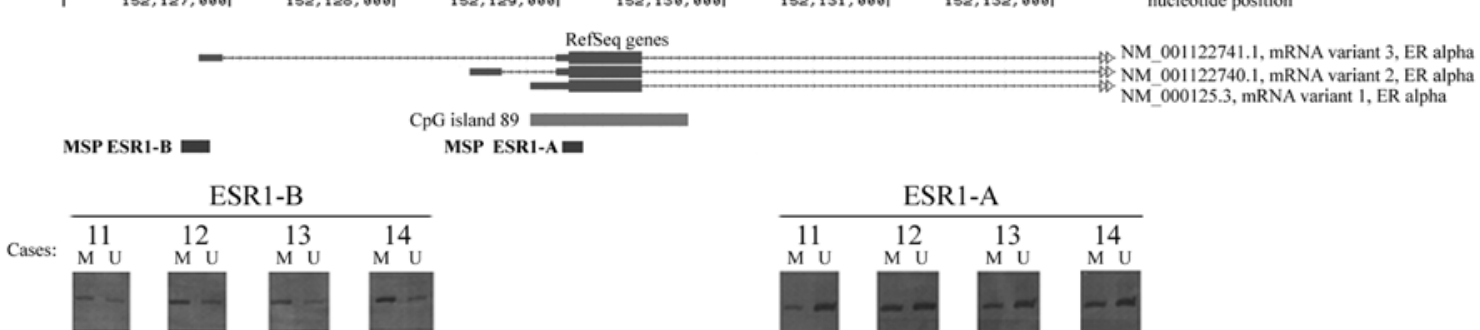

\begin{tabular}{cccc}
\multicolumn{4}{c}{ ESR1-A } \\
\hline 11 & 12 & 13 & 14 \\
$M \mathrm{U}$ & $\mathrm{M} U$ & $\mathrm{M} U$ & $\mathrm{M} U$ \\
- & - & - & -
\end{tabular}

C

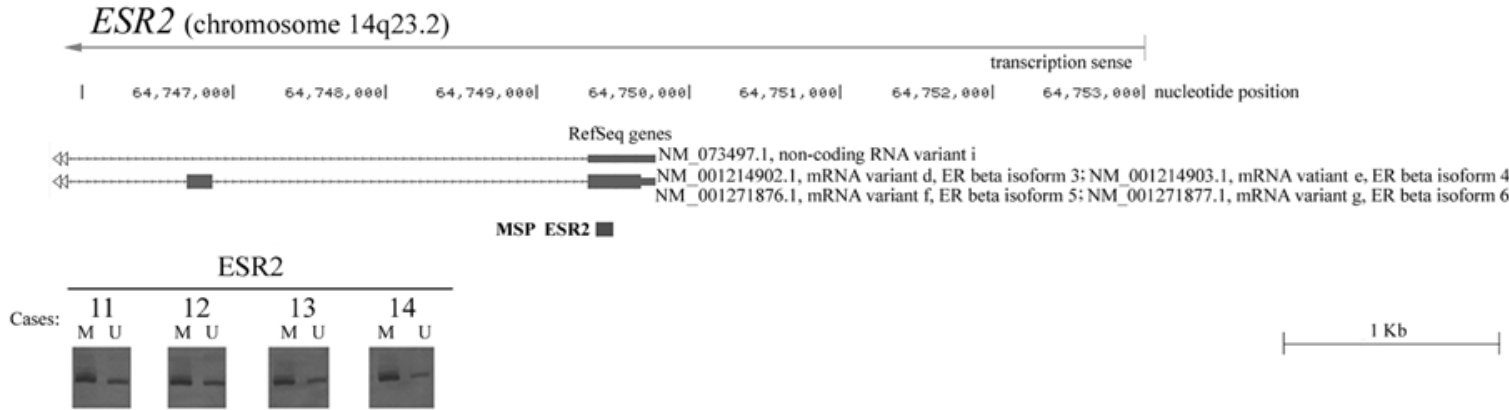

Figure 1. MS-PCR analysis of steroid receptor genes in deep endometriosis compromising the rectum. UCSC browser representation of the alternative transcripts of the PGR (A), ESR1 (B) and ESR2 (C) genes, associated CpG islands and respective MS-PCR assays [University of California Santa Cruz (UCSC) Genome Browser on Human, Feb. 2009 (GRCh37/hg19) Assembly, available at http://genome.ucsc.edu/]. (A) MS-PCR results of the PGR gene showing methylation of promoter A (cases 11, 13 and 14) and promoter B (cases 02, 07, 11 and 18). Methylated alleles in cases 02 and 07 were detected only in the deep endometriotic lesions. (B and C) Methylated and unmethylated alleles were detected evenly after MS-PCR analysis of the ESR1 (promoters A and B) and ESR2 genes in all cases. (M, methylated alleles; $\mathrm{U}$, unmethylated alleles).

methylated at both promoters (cases 11, 13 and 14). However, no statistically significant differences were observed between the presence/absence of DNA methylation of the $A$ and $B$ promoter regions of the $P G R$ gene and the stage of the lesions, histological classification, or menstrual cycle phase (Table III).

The immunostaining of the ER $\alpha, E R \beta$ and PgR proteins in the endometriotic lesions exhibited a heterogeneous pattern with the presence of both positive and negative epithelial and stromal cells (Fig. 2). Of note, some endometriotic samples showed positive staining for PgR only in the stromal component, while the epithelial component were negative (Fig. 1, case 3 and Fig. 2H). In these cases, both methylated and unmethylated alleles were identified, probably due to the epigenetic silencing mediated by DNA methylation of the $P G R$ gene in the epithelial fraction of the endometriotic lesions.

\section{Discussion}

The major finding of our study was that promoter region $B$ of the $P G R$ gene differed in regards to the methylation status between eutopic endometrium and deep endometriosis compromising the rectum: methylated alleles were specifically detected in the endometriotic lesions, while endometrium samples showed only unmethylated alleles. These data suggest that this epigenetic alteration may be a possible biomarker for endometriosis. Using the same MS-PCR primer set, Wu et al (9) reported the presence of partial methylation in this promoter in the epithelial component of peritoneal and ovarian endometriotic implants, but not in the promoter region that controls the expression of the A isoform. In addition, the authors reported low levels of $P G R B$ expression in endometriotic epithelial 

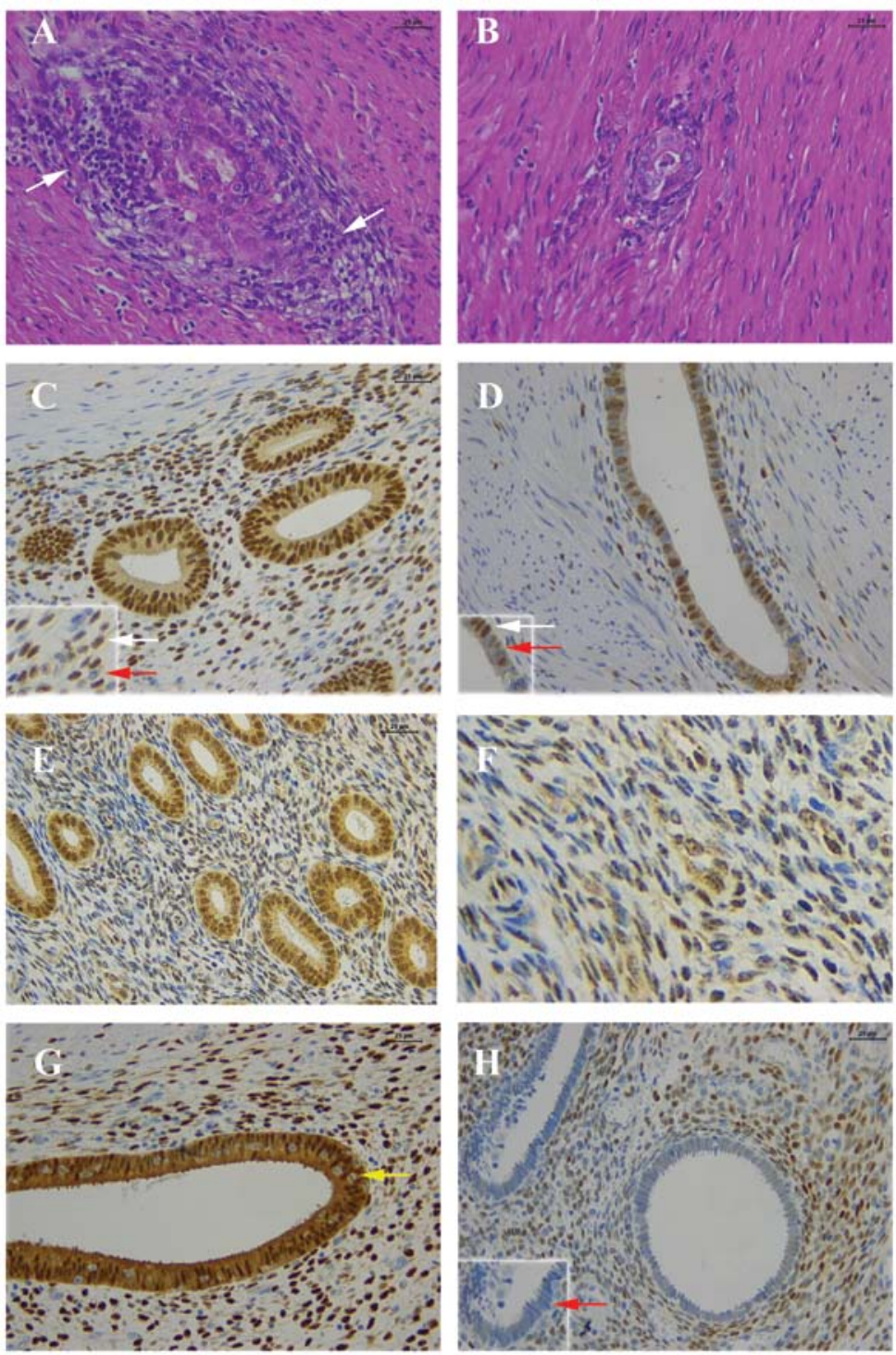

Figure 2. H\&E and immunostaining of ER $\alpha, E R \beta$ and PgR. (A) Note the moderate inflammatory infiltrate (white arrows) in the stroma of the endometriosis; H\&E. (B) Endometrial gland with scattered stroma and few inflammatory cells; H\&E. (C) Estrogen receptor $\alpha(E R \alpha)$ in the epithelial glandular cells (all cells are positive) and some positive stromal cells. Inset: detail of positive (white arrow) stromal cells and negative (red arrow) stromal cells for ER $\alpha$ (epithelium, score +4; stroma, score +3). (D) ER $\alpha$. Endometrial gland of an endometriotic intestinal focus, with positive and negative nuclear ER $\alpha$, and few positive cells in the stroma. Inset: detail of positive (white arrow) stromal cells and negative (red arrow) epithelial cells for ER $\alpha$ (epithelium, score +4 ; stroma, score +3 ). (E) Estrogen receptor $\beta(E R \beta)$. Positive nuclear staining in all epithelial cells and in most of the stromal cells (epithelium and stroma, score +4$)$; (F) ER $\beta$. Higher magnification of the stromal component of the endometriotic focus, with positive and negative cells (epithelium and stroma, score +4 ). (G) Progesterone receptor (PgR). Note that all nuclei of the epithelial cells are positive for PgR and some of the stromal cells. Inside the gland there are a number of inflammatory cells, negative for PgR (yellow arrow) (epithelium and stroma, score +4$)$. (H) PgR for case 03. All epithelial cells from the endometriotic focus are negative, and the majority of the stromal cells are positive (epithelium, negative; stroma: $3+$ ). Inset: details of the negative (red arrow) epithelial cells for PgR. Scale bar, $25 \mu \mathrm{m}$.

cells. In the present study, we demonstrated that both A and B promoter regions of the $P G R$ genes were methylated in a subset of infiltrating intestinal endometriosis.

It has been proposed that the $P G R B$ isoform is crucial for mediating the inhibitory effects of progesterone on cell growth and invasion, while PGRA has a suppressor function $(28,29)$. Thus, the results of the present study indicates the importance of DNA methylation alterations of the $P G R$ gene in a subset of infiltrative deep endometriosis, which is characterized by multifocal lesion sites, increased aggressiveness and severe clinical symptoms as compared to pelvic endometriosis, which was the type commonly investigated in previous epigenetic studies $(7,9-11,14)$.
Collectively, these data support the observation that endometriotic lesions exhibit a trend of partial methylation of the $P G R$ gene, which does not completely inactivate gene expression in the entire lesion focus, yet to some extent, is responsible for a decrease in the expression of the $\mathrm{PgR}$ receptor restricted to various areas or specific cells. These findings were validated in the present study by the heterogeneous pattern observed upon PgR immunohistochemistry (Fig. 2H), which showed positive and negative staining for the PgR receptor coexisting in the same endometriotic focus. This observation may explain the lower expression level of progesterone receptors in endometriosis and may be associated with the fact that approximately $9 \%$ of women 
with endometriosis are not responsive to treatment with progestin (5).

At present, endometriotic lesions are described as estrogendependent endometrium-like tissue consisting of glands and stroma. This abnormal tissue exhibits a unique expression profile of steroid hormone receptors as compared to matched eutopic endometrium or endometrium from women without endometriosis. Previous studies have detected lower levels of $E R \alpha$ and higher levels of ER $\beta$ in endometriosis $(30,31)$. $\mathrm{ER} \alpha$ appears to be the primary mediator of estradiol-induced progesterone action in this tissue (32), and progesterone exerts its functions in the endometrium by binding to the nuclear receptors PgRA and PgRB.

Epigenetic mechanisms modulate the dynamic regulation of the estrogen receptor genes and their functions (32). Promoter-specific DNA methylation may be causally related to the differential expression of the $\mathrm{ER} \alpha$ and $\mathrm{ER} \beta$ receptors in endometriosis. These receptors have differential affinity for ligands, are differentially expressed in a tissue-specific manner and may function antagonistically (33). Both ER isoforms exist as several splice variants. The alternative transcripts are ubiquitous, although their biological significance remains poorly understood (34). Furthermore, alternative promoter usage leads to pre-mRNAs with a variable length non-coding 5' untranslated region (35-37).

In breast cancer cell lines, ESRl expression was previously found to be suppressed by promoter DNA methylation $(38,39)$ and histone hypoacetylation (40) and was derepressed by DNA methyltransferase (5-aza-2'deoxycytidine) and histone deacetylase (trichostatin A) inhibitors $(41,42)$. Promoter region hypermethylation has also been shown to be inversely associated with ESR2 expression levels (43). In line with this, the methylation pattern of the ESRl gene was investigated in endometriosis in the present study and methylated alleles at both promoters $\mathrm{A}(E S R I A)$ and $\mathrm{B}(E S R I B)$ were found. The consequences of DNA methylation in gene expression are best understood at $\mathrm{CpG}$ island-containing promoters, however, the two promoter regions investigated in the present study, ESRIB and ESR2, are CpG island-free (Fig. 1). However, this also represents a promising gene region for further DNA methylation studies in endometriosis, since this region has been confirmed to be differentially methylated in studies investigating other diseases, such as prostate or breast cancer $(25,44)$, suggesting that the regulation of this gene by DNA methylation overlaps other complex molecular mechanisms as recently described $(45,46)$.

To the best of our knowledge, only one study has evaluated the methylation status of the ESR 2 gene in 8 ovarian endometriomas by bisulfite-modified DNA sequencing (10). The authors described high levels of ESR2 transcripts associated with hypomethylation of the respective promoter region in comparison with endometrium. In contrast, in the present study, MS-PCR analysis targeting a different region of an alternative promoter of ESR2 (Fig. 1) in matched samples of the endometria and intestinal deep endometriosis showed a more complex pattern, with methylated and unmethylated alleles in both tissues. Notwithstanding, the region investigated in this study represents the beginning of numerous new transcripts identified as expressed at premenopausal endometrium or endometriosis (GenBank, available at http://www. ncbi.nlm.nih.gov/nuccore, accession numbers AF074598 and AF074599, respectively). In this context, it is tempting to speculate whether the ESR2 gene generates multiple transcripts by triggering transcription initiation at alternative sites that could be inactivated by tissue-specific methylation. Therefore, interpretation of differential DNA methylation patterns has proven difficult, in part because the functional consequences depend on the genomic region involved, the specific $\mathrm{CpG}$ dinucleotides, and inter-tissue and intra-tissue heterogeneity. In line with this, the immunostaining performed in this study was able to indicate the heterogeneity inherent to endometriotic lesions, due to the different staining pattern between epithelial and stromal cells, or even within the same cellular component (stromal or epithelial). Furthermore, this heterogeneity was found to be increased due to the additional presence of other types of infiltrative cells, such as inflammatory cells (Fig. 2A and B).

From a translational research perspective, gene-specific methylation patterns may be useful biomarkers for detection since alterations in DNA methylation potentially provide a positive signal for endometriotic cell detection. MS-PCR is an extremely sensitive PCR-based method, and it has been used to detect hypermethylated genes in samples of limited quantity derived from patients with various types of malignancies, such as those obtained from fine needle aspiration, biopsies and corporal fluids (47). In this context, epigenetic studies may lead to the identification of the target genes of aberrant DNA methylation in endometriosis, thus representing a promising strategy for the monitoring of the onset and progression of the disease. In the present study, we showed that DNA methylation in the promoter of the $P G R B$ gene is a potential biomarker for endometriotic lesions as compared to endometrium from the same patient. Moreover, aberrant $P G R B$ methylation was able to be identified in the entire lesion focus, without the necessity of isolation of the glandular and stromal components. Thus, this epigenetic change has the potential to be considered as a useful biomarker for the pathogenesis of a subset of endometriosis consisting of intestinal deep endometriosis.

In summary, these data indicate that abnormal methylation patterns occur in deep endometriosis compromising the rectum. Further studies are clearly necessary to elucidate the possible relationship between DNA hypermethylation of the $\mathrm{A}$ and $\mathrm{B}$ promoter regions of the $P G R$ gene and progesterone resistance. In addition, future epigenetic studies involving the evaluation of steroid receptor methylation in endometriosis should consider the histological pattern and each cellular component separately (stromal or epithelial) in order to verify the effect of DNA methylation on the expression of each alternative steroid receptor transcript in this complex disorder.

\section{Acknowledgements}

The authors thank FAPESP and CAPES for their financial support. We also thank Ana Carolina Machado Poppe for technical support and Annacarolina F.L. da Silva and Alexandre Fabro for assistance with the histopathological analysis and tissue macrodissection. This study was supported by Fundação de Amparo à Pesquisa do Estado de São Paulo (FAPESP, grants 2008/53716-5 and 2008/52270-3) and Coordenação de Aperfeiçoamento de Pessoal de Nível Superior (CAPES). 


\section{References}

1. Portela A and Esteller M: Epigenetic modifications and human disease. Nat Biotechnol 28: 1057-1068, 2010.

2. Ballestar E: An introduction to epigenetics. Adv Exp Med Biol 711: 1-11, 2011

3. Illingworth RS and Bird AP: CpG islands - 'a rough guide'. FEBS Lett 583: 1713-1720, 2009.

4. Guo SW: Epigenetics of endometriosis. Mol Hum Reprod 15: 587-607, 2009

5. Bulun SE: Endometriosis. N Engl J Med 360: 268-279, 2009.

6. Nasu K, Kawano Y, Tsukamoto Y, et al: Aberrant DNA methylation status of endometriosis: epigenetics as the pathogenesis biomarker and therapeutic target. J Obstet Gynaecol Res 37: 683-695, 2011.

7. Martini M,Ciccarone M, Garganese G, et al: Possible involvement of hMLH1, p16(INK4a) and PTEN in the malignant transformation of endometriosis. Int J Cancer 102: 398-406, 2002.

8. Wu Y, Halverson G, Basir Z, Strawn E, Yan P and Guo SW: Aberrant methylation at HOXA10 may be responsible for its aberrant expression in the endometrium of patients with endometriosis. Am J Obstet Gynecol 193: 371-380, 2005.

9. Wu Y, Strawn E, Basir Z, Halverson G and Guo SW: Promoter hypermethylation of progesterone receptor isoform $B$ (PR-B) in endometriosis. Epigenetics 1: 106-111, 2006.

10. Xue Q, Lin Z, Cheng YH, et al: Promoter methylation regulates estrogen receptor 2 in human endometrium and endometriosis. Biol Reprod 77: 681-687, 2007.

11. Xue Q, Lin Z, Yin P, et al: Transcriptional activation of steroidogenic factor-1 by hypomethylation of the $5^{\prime} \mathrm{CpG}$ island in endometriosis. J Clin Endocrinol Metab 92: 3261-3267, 2007.

12. Wang D, Chen Q, Zhang C, Ren F and Li T: DNA hypomethylation of the COX-2 gene promoter is associated with up-regulation of its mRNA expression in eutopic endometrium of endometriosis. Eur J Med Res 17: 12, 2012.

13. Wu Y, Strawn E, Basir Z, Halverson G and Guo SW: Aberrant expression of deoxyribonucleic acid methyltransferases DNMT1 DNMT3A, and DNMT3B in women with endometriosis. Fertil Steril 87: 24-32, 2007.

14. Izawa M, Taniguchi F, Uegaki T, Takai E, Iwabe T, Terakawa N and Harada T: Demethylation of a nonpromoter cytosinephosphate-guanine island in the aromatase gene may cause the aberrant up-regulation in endometriotic tissues. Fertil Steril 95 33-39, 2010.

15. Bulun SE, Cheng YH, Pavone ME, et al: Estrogen receptor-beta, estrogen receptor-alpha, and progesterone resistance in endometriosis. Semin Reprod Med 28: 36-43, 2010.

16. Grandien K: Determination of transcription start sites in the human estrogen receptor gene and identification of a novel, tissue-specific, estrogen receptor-mRNA isoform. Mol Cell Endocrinol 116: 207-212, 1996.

17. Grandien K, Berkenstam A and Gustafsson JA: The estrogen receptor gene: promoter organization and expression. Int J Biochem Cell Biol 29: 1343-1369, 1997.

18. Wen DX, Xu YF, Mais DE, Goldman ME and McDonnell DP. The $\mathrm{A}$ and $\mathrm{B}$ isoforms of the human progesterone receptor operate through distinct signaling pathways within target cells Mol Cell Biol 14: 8356-8364, 1994.

19. Hirata S, Shoda T, Kato J and Hoshi K: The multiple untranslated first exons system of the human estrogen receptor beta (ER beta) gene. J Steroid Biochem Mol Biol 78: 33-40, 2001.

20. Wills HJ, Reid GD, Cooper MJ and Morgan M: Fertility and pain outcomes following laparoscopic segmental bowel resection for colorectal endometriosis: a review. Aust NZ J Obstet Gynaecol 48: 292-295, 2008

21. No authors listed: Revised American Society for Reproductive Medicine classification of endometriosis. Fertil Steril 67 817-821, 1997.

22. Abrao MS, Neme RM, Carvalho FM, Aldrighi JM and Pinotti JA: Histological classification of endometriosis as a predictor of response to treatment. Int J Gynaecol Obstet 82: 31-40, 2003

23. Pires AR, da Matta Andreiulo F and de Souza SR: TMA for all: a new method for the construction of tissue microarrays without recipient paraffin block using custom-built needles. Diagn Pathol 1: 14,2006

24. Negraes PD, Favaro FP, Camargo JL, Oliveira ML, Goldberg J, Rainho CA and Salvadori DM: DNA methylation patterns in bladder cancer and washing cell sediments: a perspective for tumor recurrence detection. BMC Cancer 8: 238, 2008
25. Sasaki M, Tanaka Y, Perinchery G, Dharia A, Kotcherguina I Fujimoto $S$ and Dahiya R: Methylation and inactivation of estrogen, progesterone, and androgen receptors in prostate cancer. J Natl Cancer Inst 94: 384-390, 2002.

26. Neve RM, Chin K, Fridlyand J, et al: A collection of breast cancer cell lines for the study of functionally distinct cancer subtypes. Cancer Cell 10: 515-527, 2006.

27. Gu F, Doderer MS, Huang YW, et al: CMS: a web-based system for visualization and analysis of genome-wide methylation data of human cancers. PLoS One 8: e60980, 2013.

28. Dai D, Wolf DM, Litman ES, White MJ and Leslie KK: Progesterone inhibits human endometrial cancer cell growth and invasiveness: down-regulation of cellular adhesion molecules through progesterone B receptors. Cancer Res 62: 881-886, 2002.

29. Wu Y, Shi X and Guo SW: The knockdown of progesterone receptor isoform $\mathrm{B}$ (PR-B) promotes proliferation in immortalized endometrial stromal cells. Fertil Steril 90: 1320-1323, 2008

30. Brandenberger AW, Lebovic DI, Tee MK, Ryan IP, Tseng JF, Jaffe RB and Taylor RN: Oestrogen receptor (ER)-alpha and ER-beta isoforms in normal endometrial and endometriosisderived stromal cells. Mol Hum Reprod 5: 651-655, 1999.

31. Fujimoto J, Hirose R, Sakaguchi $\mathrm{H}$ and Tamaya T: Expression of oestrogen receptor-alpha and -beta in ovarian endometriomata. Mol Hum Reprod 8: 742-747, 1999.

32. Leader JE, Wang C, Popov VM, Fu M and Pestell RG: Epigenetics and the estrogen receptor. Ann NY Acad Sci 1089: 73-87, 2006.

33. Ström A, Hartman J, Foster JS, Kietz S, Wimalasena J and Gustafsson JA: Estrogen receptor beta inhibits 17beta-estradiolstimulated proliferation of the breast cancer cell line T47D. Proc Natl Acad Sci USA 101: 1566-1571, 2004.

34. Taylor SE, Martin-Hirsch PL and Martin FL: Oestrogen receptor splice variants in the pathogenesis of disease. Cancer Lett 288 133-148, 2010

35. Flouriot G, Griffin C, Kenealy M, Sonntag-Buck V and Gannon F: Differentially expressed messenger RNA isoforms of the human estrogen receptor-alpha gene are generated by alternative splicing and promoter usage. Mol Endocrinol 12: 1939-1954, 1998.

36. Lu B, Leygue E, Dotzlaw H, Murphy LJ, Murphy LC and Watson PH: Estrogen receptor-beta mRNA variants in human and murine tissues. Mol Cell Endocrinol 138: 199-203, 1998.

37. Lu B, Dotzlaw H, Leygue E, Murphy LJ, Watson PH and Murphy LC: Estrogen receptor-alpha mRNA variants in murine and human tissues. Mol Cell Endocrinol 158: 153-161, 1999.

38. Ottaviano YL, Issa JP, Parl FF, Smith HS, Baylin SB and Davidson NE: Methylation of the estrogen receptor gene $\mathrm{CpG}$ island marks loss of estrogen receptor expression in human breast cancer cells. Cancer Res 54: 2552-2555, 1994.

39. Lapidus RG, Nass SJ and Davidson NE: The loss of estrogen and progesterone receptor gene expression in human breast cancer. J Mammary Gland Biol Neoplasia 3: 85-94, 1998.

40. Sharma D, Saxena NK, Davidson NE and Vertino PM: Restoration of tamoxifen sensitivity in estrogen receptor-negative breast cancer cells: tamoxifen-bound reactivated ER recruits distinctive corepressor complexes. Cancer Res 66: 6370-6378, 2006.

41. Macaluso M, Montanari M, Noto PB, Gregorio V, Bronner C and Giordano A: Epigenetic modulation of estrogen receptor-alpha by $\mathrm{pRb}$ family proteins: a novel mechanism in breast cancer. Cancer Res 67: 7731-7737, 2007.

42. Sharma D, Blum J, Yang X, Beaulieu N, Macleod AR and Davidson NE: Release of methyl CpG binding proteins and histone deacetylase 1 from the estrogen receptor alpha (ER) promoter upon reactivation in ER-negative human breast cancer cells. Mol Endocrinol 19: 1740-1751, 2005.

43. Rody A, Holtrich U, Solbach C, et al: Methylation of estrogen receptor beta promoter correlates with loss of ER-beta expression in mammary carcinoma and is an early indication marker in premalignant lesions. Endocr Relat Cancer 12: 903-916, 2005.

44. Zhao L, Yu Z, Li Y, et al: Clinical implications of ER $\beta$ methylation on sporadic breast cancers in Chinese women. Med Oncol 29: 1569-1575, 2012.

45. Han H, Cortez CC, Yang X, Nichols PW, Jones PA and Liang G: DNA methylation directly silences genes with non-CpG island promoters and establishes a nucleosome occupied promoter. Hum Mol Genet 20: 4299-4310, 2011.

46. Zelenko Z, Aghajanova L, Irwin JC and Giudice LC: Nuclear receptor, coregulator signaling, and chromatin remodeling pathways suggest involvement of the epigenome in the steroid hormone response of endometrium and abnormalities in endometriosis. Reprod Sci 19: 152-162, 2012.

47. Laird PW: The power and the promise of DNA methylation markers. Nat Rev Cancer 3: 253-266, 2003. 